\title{
PENGUJIAN NUTRISI ORGANIK CAIR PLUS AGENS HAYATI PADA SISTEM NUTRIENT FILM TECHNIQUE (NFT) HIDROPONIK TANAMAN KANGKUNG (Ipomoea aquatica)
}

\author{
Disusun oleh : \\ Ramli**) \\ Muhammad Nabil Makky*)
}

\begin{abstract}
Abstrak
Limbah sayuran dan kulit pisang mengandung nutrisi yang diperlukan oleh tanaman seperti nitrogen, karbohidrat dan lain-lain. Limbah sayuran dan kulit pisang dapat diaplikasikan sebagai pupuk organik cair. Penggunaan agens hayati Paenibacillus polymyxa sebagai pupuk hayati diyakini mampu memperbaiki kualitas akar tanaman serta mengurangi penggunaan pupuk kimia. Penelitian ini bertujuan untuk mengetahui efektivitas POC Sayuran dan Kulit Pisang plus agens hayati Paenibacillus polymyxa terhadap pertumbuhan tanaman kangkung dengan sistem hidroponik. Penelitian ini menggunakan metode eksperimen dengan Rancangan Acak Lengkap (RAL) yang terdiri dari perlakuan yaitu jenis POC plus agens hayati Q0 : AB mix (control), Q1 : POC Sayuran plus agens hayati, Q2 : POC Kulit Pisang plus agens hayati, 3 perlakuan dan 4 ulangan. Hasil uji Tukey Alpha 5\% menunjukkan nilai tertinggi tinggi tanaman perlakuan $\mathrm{Q} 0$ : pupuk cair $\mathrm{AB}$ mix yaitu $26.52 \mathrm{~cm}$, jumlah daun perlakuan Q2 : POC kulit pisang plus agens hayati yaitu 11 helai, bobot basah perlakuan Q0 : $\mathrm{AB}$ mix yaitu $4.00 \mathrm{~g}$. dan panjang akar perlakuan Q2 : POC kulit pisang plus agens hayati $11.32 \mathrm{~cm}$.
\end{abstract}

Kata Kunci : AB mix, kulit pisang, limbah sayuran, Paenibacillus polymyxa.

\section{Abstrack}

Vegetable waste and banana peels contain nutrients needed by plants such as nitrogen, carbohydrates and others. Vegetable waste and banana peels can be applied as liquid organic fertilizer. The use of biological fertilizer is believed to be able to improve the quality of plant roots and reduce the use of chemical fertilizers. The purpose of this research was to determine the effectiveness of vegetable and banana liquid organic fertilizer plus biological agent Paenibacillus polymyxa on the growth of water spinach plants with a bydroponic system. This study used an experimental method with a Completely Randomized Design (CRD) which consisted of 3 treatments namely the type of organic liquid fertilizer plus biological agents $Q 0: A B$ mix (control), $Q^{1}$ : $V$ egetable waste liquid fertilizer plus biological agents, Q2 : banana peels liquid fertilizer plus biological agents, three treatments and four replications. Tukey Alpha 5\% test result showed the highest $Q 0: A B$ mix liquid fertilizer was $26.52 \mathrm{~cm}$, the number of leaves Q2 : banana peels liquid fertilizer plus biological agents treatment, the wet weight of the treatment $Q 0: A B$ mix was $4.00 \mathrm{~g}$, and root length of treatment $Q 2$ : banana peels liquid fertilizerer plus biological agents liquid fertilizer plus biological agents was $11.32 \mathrm{~cm}$.

Keywords : AB mix, banana peels, Paenibacillus polymyxa, vegetable waste.

*) Alumni Fakultas Sains Terapan UNSUR

**) Dosen Fakultas Sains Terapan UNSUR

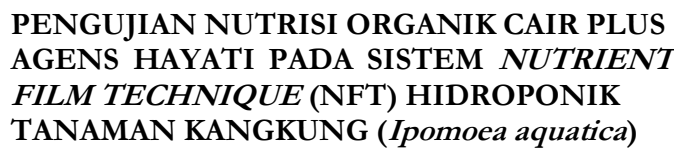

RAMLI

MUHAMMAD NABIL MAKKY 


\section{PENDAHULUAN}

Tanaman kangkung (Ipomoea aquatica) termasuk tanaman sayuran yang berumur pendek. Daun kangkung mempunyai peran penting bagi perekonomian Indonesia. Kebutuhan kangkung akan meningkat akibat pertumbuhan jumlah penduduk, juga akibat perubahan pola konsumsi di beberapa negara berkembang. Alasan kangkung sangat digemari oleh masyarakat, karena kangkung memiliki kandungan gizi yang cukup tinggi (Rukmana, 1993).

Kebanyakan budidaya yang dilakukan khususnya di Indoneisa adalah budidaya konvensional. Dewasa ini, masyarakat sudah mulai mengenal istilah teknologi hidroponik. Teknologi hidroponik adalah teknologi budidaya modern yang sangat efisien untuk melakukan budidaya terutama tanaman hortikultura. Hal itu terjadi karena teknologi hidroponik tidak mengenal musim dan tidak memerlukan lahan yang luas untuk menghasilkan produk yang sama (Lonardy, 2006).

Menurut Indrawati

hidroponik NFT adalah teknik pemberian larutan nutrisi melalui aliran tersirkulasi yang sangat dangkal. Air yang mengandung semua nutrisi terlarut tersebut diberikan secara terus menerus selama 24 jam. Adapun kelebihan dari sistem ini yaitu suplai air, oksigen dan nutrisi tercukupi karena dilakukan secara terus-menerus. Lapisan aliran sangat dangkal tipis seperti film, sehingga sebagian akar tanaman terendam dalam lapisan larutan dan sebagian lagi berada pada bagian atasnya.

Penggunaan agens hayati Paenibacillus polymyxa diformulasikan dalam bentuk cairan bersamaan dengan POC. Larutan POC disinyalir mengandung unsur hara makro, mikro, atau mengandung mikroorganisme yang berpotensi sebagai perombak bahan organik, perangsang pertumbuhan, dan agen pengendali hama dan penyakit tanaman sehingga baik digunakan sebagai dekomposer, pupuk hayati, atau pestisida organik (Purwasasmita, 2009).

Menurut Hadisuwito (2007) pupuk organik cair dapat dibuat dari beberapa jenis sampah organik yaitu sampah sayur baru, sisa sayuran basi, kulit pisang, sisa nasi, sisa ikan, ayam, kulit telur, sampah buah seperti anggur, kulit jeruk, apel dan lain-lain.

Menurut Susetya (2012) kulit pisang memiliki beberapa kandungan yakni protein, kalsium, fosfor, magnesium, sodium dan sulphur, sehingga kulit pisang memiliki potensi yang bagus untuk dijadikan pupuk organik. Kandungan unsur hara yang terdapat pada kulit pisang sangat berguna untuk pertumbuhan tanaman seperti yang dikatakana Nasution et al., (2014) bahwa kandungan yang ada pada pupuk organik cair kulit pisang yaitu, C-organik 0,55\%, $\mathrm{N}$-total $\quad 0,18 \% ; \quad \mathrm{P} 2 \mathrm{O} 5 \quad 0,043 \% ; \quad \mathrm{K} 2 \mathrm{O}$ 1,137\%; C/N 3,06\% dan pH 4,5.

Pupuk kandang seperti kotoran dan urine kelinci adalah pupuk yang memiliki kandungan unsur $\mathrm{N}=2,72 \%$, $\mathrm{P}=1,1 \%, \mathrm{~K}=0,5 \%$ yang lebih tinggi dibandingkan dengan kotoran ternak lain seperti kuda, kerbau, sapi, domba, babi dan ayam (Nurrohman et al., 2014). Bakteri Paenibacillus polymixa adalah bakteri yang dapat membantu pertumbuhan dan perkembangan tumbuhan. Bakteri dilarutkan pada pupuk organik cair bersamaan dengan urine kelinci serta bahan organik lainnya. Paenibacillus polymyxa adalah bakteri non patogen yang menguntungkan di bidang kesehatan dan lingkungan. Bakteri ini penghasil antibiotik polimiksin. Antibiotik polimiksin merupakan zat yang dihasilkan oleh mikroorganisme dan mempunyai daya hambat terhadap kegiatan mikroorganisme lain. Beberapa penelitian terdahulu telah menemukan pengobatan tanaman dengan Paenibacillus polymyxa di lapangan seperti fiksasi nitrogen, fosfor, 
produksi antibiotik, auksin, sitokinin, enzim kitinase dan hidrolitik serta promosi peningkatan porositas tanah. Selain itu beberapa efek antagonis Paenibacillus polymyxa pada penelitian terdahulu telah menunjukkan bahwa Paenibacillus polymyxa memusuhi pathogen oomycetic (Timmusk et al., 2003).

Widarti dan Sugeng (2014) menambahkan bakteri Paenibacillus polymyxa mampu mengikat nitrogen dan biofilms dari bakteri Paenibacillus polymyxa menunjukkan produksi eksopolysakarida pada akar tanaman yang dapat melindungi tanaman dari patogen.

Tujuan dari penelitian ini adalah untuk mengetahui pengaruh berbagai jenis POC limbah rumah tangga plus agens hayati Paenibacillus polymyxa pada sistem budidaya hidroponik dengan teknologi NFT, terhadap parameter pertumbuhan (Tinggi tanaman, Jumlah daun, Berat Basah dan Panjang akar) tanaman kangkung (Ipomoea aquatica).

\section{METODE PENELITIAN}

Jenis penelitian ini adalah penelitian eksperimen yang menggunakan rancangan acak lengkap yang terdiri dari jenis POC 2 konsentrasi, dengan 3 perlakuan yaitu $\mathrm{Q} 0=$ pupuk $\mathrm{AB}$ mix (kontrol), Q1 = POC sayuran Q2 = POC kulit pisang dan kepekatan masing-masing perlakuan 1000 ppm. Setiap sayuran kangkung diberi 3 perlakuan, setiap perlakuan diulang sebanyak 4 ulangan, parameter yang diamati 10 tanaman. Sehingga terdapat 120 tanaman yang, paranet, alat tulis, dan kamera. Bahan yang digunakan yaitu : benih kangkung, EM4, POC dari limbah kulit pisang dan limbah sayuran plus agen hayati Paenibacillus polymyxa, air.

Penelitian dilaksanakan pada bulan Juli sampai bulan September 2019 dimulai dari persiapan, pengumpulan dan analisis data, serta penulisan laporan. Lokasi penelitian bertempat di
HollywoodFarm, Jl. Raya CianjurBandung km 5, Karang Tengah, Cianjur, Jawa Barat.

\section{HASIL DAN PEMBAHASAN}

Pertumbuhan tanaman kangkung pada penelitian ini diukur melalui 4 parameter yaitu tinggi tanaman (cm), jumlah daun (helai), bobot basah (gram) dan panjang akar (cm). Proses pengukuran yang dilakukan yaitu pengukuran tinggi dan panjang akar tanaman dilakukan secara manual dengan menggunakan alat tulis dan mistar, bobot basah menggunakan timbangan gram digital dan jumlah daun dihitung secara manual. Pengukuran tinggi dan jumlah daun tanaman dilakukan pada 1 MST, 2 MST, 3 MST dan 4 MST. Pengukuran bobot basah dan panjang akar dilakukan pada 4 MST.

\section{Tinggi Tanaman}

Pengamatan Tinggi tanaman kangkung dilakukan mulai 1 minggu setelah tanam sampai 4 minggu setelah tanam. Hasil analisis sidik ragam terhadap semua perlakuan menunjukkan perlakuan pemberian pupuk cair berpengaruh nyata terhadap tinggi tanaman kangkung. Hasil analisis uji lanjut dengan menggunakan uji Tukey pada taraf 5\% mulai usia tanam 1 MST sampai 4 MST menunjukkan bahwa perlakuan pupuk cair AB mix (Q0) memiliki nilai tinggi tanaman kangkung tertinggi dan berbeda nyata dengan perlakuan POC sayuran (Q1) dan POC kulit pisang (Q2).

Pupuk cair AB mix merupakan pupuk cair sintetik dan mempunyai ketersedian unsur hara yang cukup untuk pertumbuhan tinggi tanaman kangkung. Sedangkan pupuk organik cair sayuran dan kulit pisang diduga memiliki unsur hara yang rendah.. Menurut Muhadiansyah (2016), unsur hara yang terkandung di dalam pupuk organik cair tersebut belum dapat menggantikan unsur hara yang terkandung di dalam pupuk $\mathrm{AB}$ Mix. 


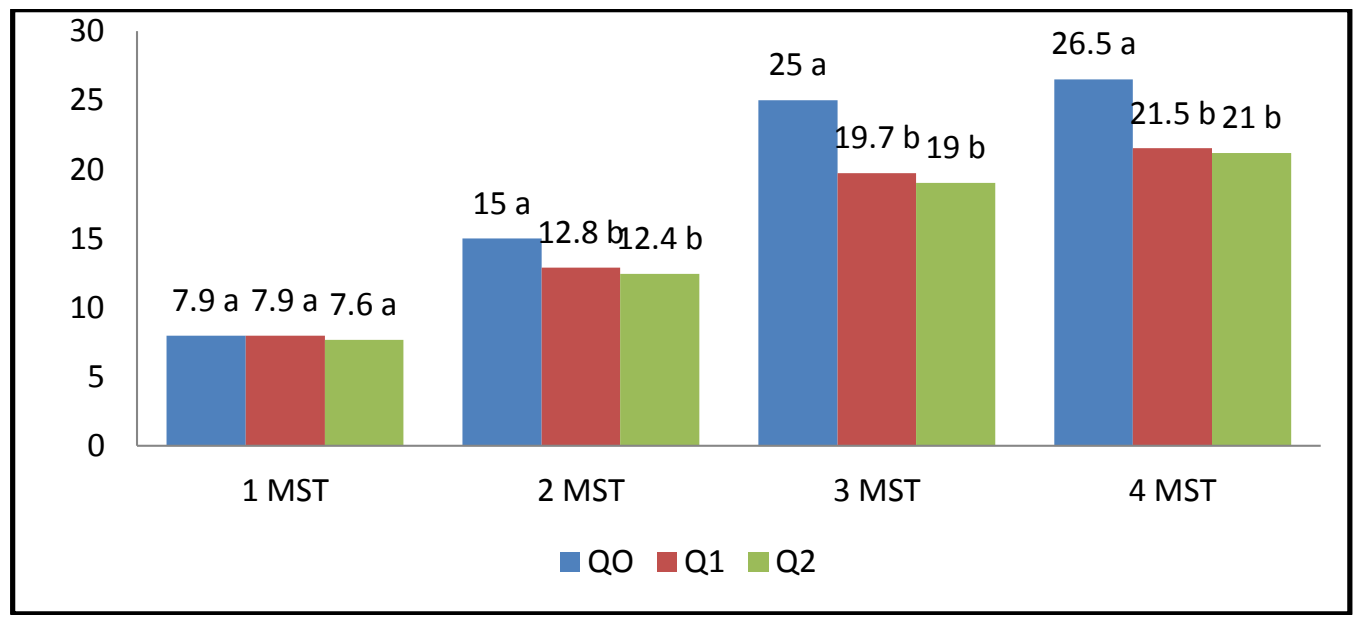

Gambar 1. Grafik rata-rata pertumbuhan Tinggi Tanaman kangkung selama 4 MST (Ket: Q0 : pupuk AB mix sebagai control, Q1 : POC sayuran, Q2 : POC kulit pisang dengan kepekatan masing-masing $1000 \mathrm{ppm})$. MST : Minggu Setelah Tanam.

\section{Jumlah Daun}

Jumlah daun menjadi parameter pengukuran selanjutnya pada penelitian ini. Setelah dilakukan analisis sidik ragam terhadap tiga perlakuan pupuk cair, hasil yang didapatkan adalah semua perlakuan tidak berpengaruh nyata terhadap jumlah daun. Sehingga hasil yang didapatkan dari perlakuan Q0, Q1, Q2 menunjukkan tidak terdapat perbedaan yang signifikan. Hal itu diduga karena tercukupinya dosis nutrisi yang diberikan pada larutan nutrisi perlakuan Q0 : AB mix, Q1 : POC sayur plus agens hayati dan Q2 : POC kulit pisang plus agens hayati untuk perkembangan jumlah daun.

Tabel 1. Tinggi Tanaman.

\begin{tabular}{ccccc}
\hline \multirow{2}{*}{ Perlakuan } & \multicolumn{4}{c}{ Jumlah Daun (helai) } \\
\cline { 2 - 5 } & 1 MST & 2 MST & 3 MST & 4 MST \\
\hline QO & $3.9 \mathrm{a}$ & $6.57 \mathrm{a}$ & $10.22 \mathrm{a}$ & $9.15 \mathrm{a}$ \\
Q1 & $4 \mathrm{a}$ & $6.42 \mathrm{a}$ & $9.65 \mathrm{a}$ & $10.05 \mathrm{a}$ \\
Q2 & $4 \mathrm{a}$ & $6.15 \mathrm{a}$ & $9.4 \mathrm{a}$ & $10.60 \mathrm{a}$ \\
\hline
\end{tabular}

Keterangan : Rata-rata pertumbuhan Jumlah Daun Tanaman kangkung selama 4 MST. Perlakuan Q0 : pupuk AB mix sebagai control, perlakuan Q1 : POC sayuran plus agens hayati, perlakuan Q2 : POC kulit pisang plus agens hayati dengan kepekatan masing-masing 1000 ppm. MST : Minggu Setelah Tanam.

Salisbury dan Ross (1995) menyatakan bahwa pupuk organik cair selain mengandung nitrogen yang menyusun dari semua protein, asam nukleat dan klorofil juga mengandung unsur hara mikro antara lain unsur $\mathrm{Mn}$, $\mathrm{Zn}, \mathrm{Fe}, \mathrm{S}, \mathrm{B}, \mathrm{Ca}$ dan $\mathrm{Mg}$. Unsur hara mikro tersebut berperan sebagai katalisator dalam proses sintesis protein dan pembentukan klorofil.

Poerwowidodo (1992) menyatakan bahwa protein merupakan penyusun utama protoplasma yang berfungsi sebagai pusat proses metabolisme dalam tanaman yang selanjutnya akan memacu pembelahan dan pemanjangan sel. Unsur hara nitrogen dan unsur hara mikro tersebut berperan sebagai penyusun klorofil sehingga meningkatkan aktivitas fotosintesis tersebut akan menghasilkan fotosintat yang mengakibatkan perkembangan pada jaringan meristematis daun. 


\section{Bobot basah}

Parameter selanjutnya pada penelitian ini adalah pengukuran bobot basah dari tanaman kangkung. Berdasarkan hasil analisis sidik ragam menunjukkan bahwa perlakuan $\mathrm{Q} 0$ : $\mathrm{AB}$ mix berpengaruh terhadap bobot basah tanaman kangkung. Setelah diuji lanjut uji Tukey Alpha 5\%, perlakuan yang menghasilkan bobot basah terberat adalah perlakuan Q0 dan berbeda nyata dengan perlakuan Q1 dan Q2.

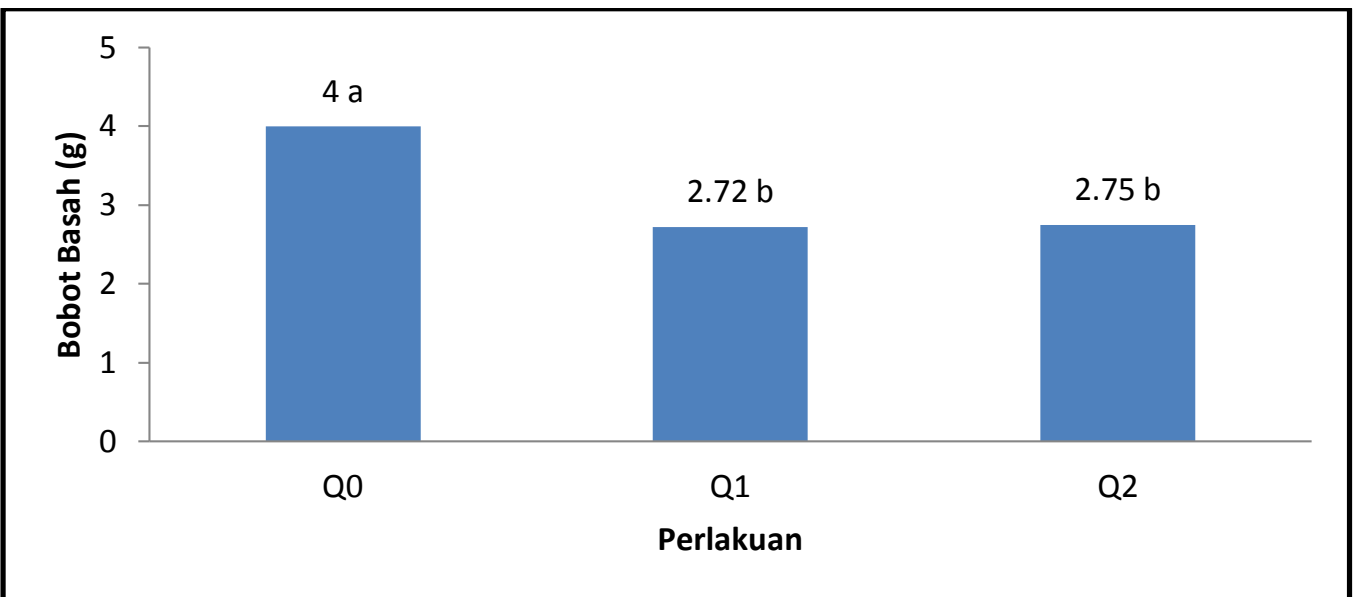

Gambar 3. Grafik rata-rata Bobot Basah Tanaman kangkung selama 4 MST (Ket: Q0 : pupuk AB mix sebagai control, Q1 : POC sayuran plus agens hayati plus agens hayati, Q2 : POC kulit pisang dengan kepekatan masing-masing 1000 ppm). MST : Minggu Setelah Tanam.

Perlakuan Q0 : AB mix memiliki nilai tertinggi pada parameter bobot basah. Berbeda nyata dengan perlakuan Q1 : POC sayuran plus agens hayati dan Q2 : POC kulit pisang plus agens hayati. Hal ini diduga tercukupinya unsur hara pada perlakuan Q0 dan kurangnya unsur hara pada perlakuan Q1 dan Q2.

Lingga (2002) mengatakan jika unsur hara yang dibutuhkan tanaman tersedia dalam jumlah yang cukup, maka hasil metabolisme seperti sintesis biomolekul akan meningkat. Hal ini menyebabkan pembelahan sel, pemanjangan dan pendewasaan jaringan menjadi lebih sempurna dan cepat, sehingga pertambahan volume dan bobot kian cepat yang pada akhirnya pertumbuhan tanaman menjadi lebih baik.

Perlakuan Q0 : AB mix memiliki nilai bobot basah terberat yaitu 4.00g. Perlakuan Q0 berbeda nyata dengan perlakuan Q1 dan Q2. Namun perlakuan Q1 dan Q2 memiliki nilai rata-rata bobot basah tidak berbeda nyata. Hasil penelitian menunjukkan perlakuan POC tanpa pupuk $\mathrm{AB}$ Mix mengalami kekurangan unsur hara mikro yaitu $\mathrm{Zn}$, Mo, Fe, Mn, Co, dan B. Walaupun dibutuhkan dalam jumlah sedikit tetapi unsur-unsur tersebut sangat mutlak dan dapat menyebabkan tanaman menjadi kurang subur. Menurut Supari (1999), kekurangan unsur hara $\mathrm{Zn}, \mathrm{Mo}, \mathrm{Fe}, \mathrm{Mn}$, Co dan $B$ dapat mempengaruhi pertumbuhan vegetatif.

\section{Panjang Akar}

Parameter selanjutnya pada penelitian ini adalah panjang akar dari tanaman kangkung. Berdasarkan hasil analisis menunjukkan bahwa perlakuan pemberian POC sayur plus agens hayati dan POC kulit pisang plus agens hayati berpengaruh nyata terhadap bobot basah tanaman kangkung. Setelah diuji lanjut uji Tukey Alpha 5\%, perlakuan yang menghasilkan panjang akar terbaik adalah perlakuan Q1 : POC sayuran dan Q2 : POC kulit pisang berbeda nyata dengan perlakuan $\mathrm{Q} 0$ : $\mathrm{AB}$ mix. 


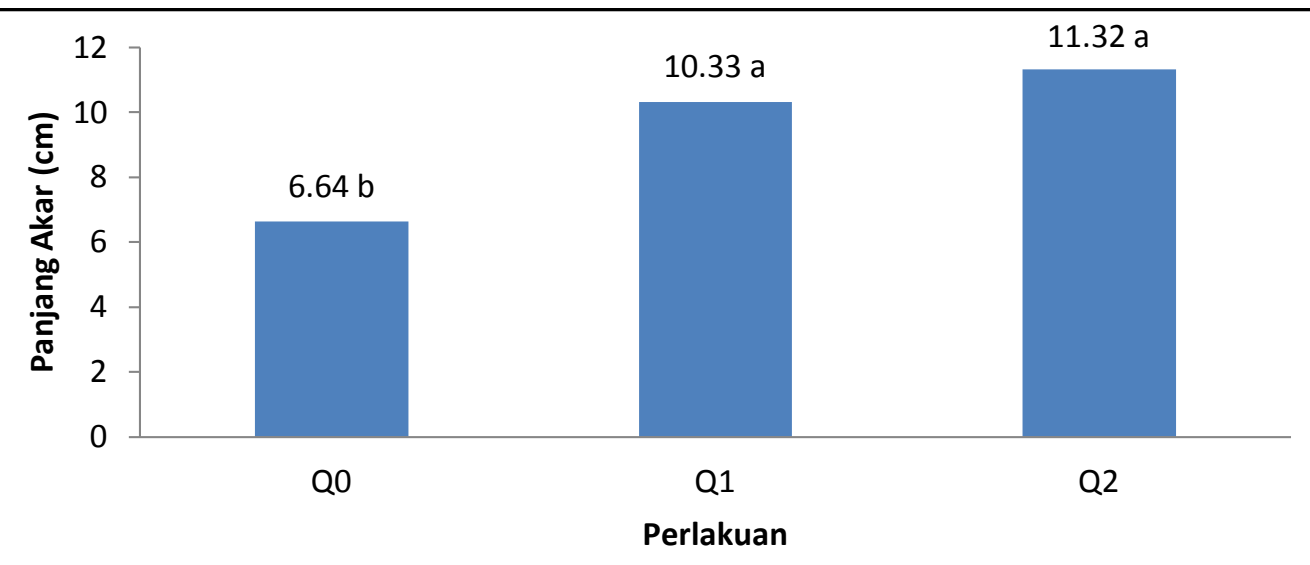

Gambar 4. Grafik rata-rata pertumbuhan Panjang akar Tanaman kangkung selama 4 MST (Ket: Q0 : pupuk AB mix sebagai control, Q1 : POC sayuran plus agens hayati, Q2 : POC kulit pisang plus agens hayati, dengan kepekatan masing-masing 1000 ppm). MST : Minggu Setelah Tanam.

Perlakuan Q2 : POC kulit pisang plus agens hayati memiliki nilai terpanjang pada parameter panjang akar yaitu 11.32 $\mathrm{cm}$ tidak berbeda nyata dengan perlakuan Q1 : POC sayuran plus agens hayati. Perlakuan Q0 : AB mix memiliki nilai terendah pada parameter panjang akar. Hal ini diduga karena adanya peran agens hayati Paenibacillus polymyxa yang ditambahkan pada POC sayur dan kulit pisang. Paenibacillus polymyxa merupakan bakteri non patogen yang menguntungkan di bidang kesehatan dan lingkungan. Bakteri ini penghasil antibiotik polimiksin. Antibiotik polimiksin merupakan zat yang dihasilkan oleh mikroorganisme dan mempunyai daya hambat terhadap kegiatan mikroorganisme lain. Timmusk (2003) mengatakan bahwa beberapa penelitian terdahulu telah menemukan pengobatan tanaman dengan Paenibacillus polymyxa di lapangan termasuk fiksasi nitrogen, fosfor, produksi antibiotik, auksin, sitokinin, enzim kitinase dan hidrolitik serta promosi peningkatan porositas tanah.

Lal dan Tabacchioni (2009) juga mengatakan bakteri Paenibacillus polymyxa memiliki berbagai manfaat, termasuk fiksasi nitrogen, promosi pertumbuhan tanaman, solubilisasi fosfor tanah dan produksi exopolysakarida, enzim hidrolitik, antibiotik, sitokinin. Widarti dan Sugeng (2014) menambahkan bakteri Paenibacillus polymyxa mampu mengikat nitrogen dan biofilms dari bakteri Paenibacillus polymyxa menunjukkan produksi eksopolysakarida pada akar tanaman yang dapat melindungi tanaman dari patogen. Hasil uji di BB Biogen bakteri Paenibacillus polymyxa juga mengandung hormon pengatur gibberellin.

\section{KESIMPULAN}

Berdasarkan hasil penelitian, maka dapat disimpulkan bahwa perlakuan pemberian pupuk cair $\mathrm{AB}$ mix berpengaruh nyata terhadap pertumbuhan tinggi dan bobot basah tanaman kangkung, namun, tidak berpengaruh nyata pada jumlah daun dan panjang akar tanaman kangkung. Hasil uji lanjut menunjukkan nilai tertinggi tinggi tanaman perlakuan $\mathrm{Q} 0$ : pupuk cair $\mathrm{AB}$ mix yaitu $26.52 \mathrm{~cm}$, jumlah daun perlakuan Q2 : POC kulit pisang plus agens hayati yaitu 11 helai, bobot basah perlakuan $\mathrm{Q} 0$ : $\mathrm{AB}$ mix yaitu $4.00 \mathrm{~g}$. dan panjang akar perlakuan Q2 : POC kulit pisang plus agens hayati $11.32 \mathrm{~cm}$. 


\section{DAFTAR PUSTAKA}

Hadisuwito, S. 2007. Membuat Рирuk Kompos Cair. Jakarta: Agromedia Pustaka.

Indrawati, R., Indradewa, D., dan Utami, S. N. H. 2012. Pengaruh komposisi media dan kadar nutrisi hidroponik terhadap pertumbuhan dan hasil tomat (Lycopersicon esculentum Mill.). Vegetalika, $3: 109-119$.

Lal, S and Tabacchioni, S. 2009. "Ecology and Biotechnological Potential of Paenibacillus polymyxa". Indian Journal of Microbiology, http://link.springer.com/article.

Lingga, P. 2002. Hidroponik Bercocok Tanam Tanpa Tanah. Penebar Swadaya. Depok.

Lonardy, M. V. 2006. Respons tanaman tomat (Lycopersicon esculentum mill.) terhadap suplai senyawa nitrogen dari sumber berbeda pada sistem hidroponik. (Skripsi). Universitas Tadulako. Palu.

Muhadiansyah, T.O, Setyono dan S.A Admiharja. 2016. Efektifitas Pencampuran Pupuk Organik Cair dalam Nutrisi Hidroponik pada Pertumbuhan dan Produksi Tanaman Selada (Lactuca sativa L.). Jurnal Agronida.

Nasution, F.J., L. Mawarni dan Meiriani. 2014. Aplikasi pupuk organik padat dan cair dari kulit pisang kapok untuk pertumbuhan dan produksi tanaman sawi Brassica juncea L.). Jurnal Agroekoteknologi Universitas Sumatera Utara.

Nurrohman M., Suryanto A. dan Karuniawan P. W., 2014. Penggunaan Fermentasi Ekstrak Paitan (Tithonia diversifolia L.) dan
Kotoran Kelinci Cair Sebagai Sumber Hara pada Budidaya Sawi (Brassica Juncea L.) Secara Hidroponik Rakit Apung. Jurnal Produksi Tanaman.

Poerwowidodo, 1992. Telaah Kesuburan Tanah. Bandung. Penerbit Angkasa.

Purwasasmita, M. 2009. Pemanfaatan Larutan MOL. http://riefarm.blogspot.com/. Diakses pada tanggal : 3 Agustus 2019

Rukmana, R. 1993. Bertanam Kangkung. Yogyakarta. Kanisius.

Salisbury, B. F. dan C. C.W Ross. 1995. Fisiologi Tumbuban. Jilid 3 ITB Bandung.

Supari, D. 1999. Seri Praktik Ciputri Hijan Tuntunan Membangun Agribisnis I. Jakarta. PT. Elek Media Komputindo Gramedia.

Susetya, D. 2012. Panduan Lengkap Membuat Pupuk Organik. Jakarta. Penerbit Baru Press.

Timmusk, S. 2003. Mechanism of Action of the Plant Growth Promoting Bacterium Paenibacillus Polymyxa. PhD thesis, Uppsala. Uppsala University.

Timmusk, S., P. van West, N. A. R. Gow, and E. G. H. Wagner. 2003. Antagonistic effects of Paenibacillus polymyxa towards the oomycete plant pathogens Phytophthora palmivora and Pythium aphanidermatum, p. 128. In Mechanism of action of the plant growth promoting bacterium Paenibacillus polymyxa. Uppsala University, Uppsala, Sweden.

Widarti, A dan Sugeng, B. 2014. Artikel Paenibacillus polymyxa. 